\title{
Classification of the coefficient of variation to variables in beef cattle experiments
}

\author{
Marcos André Braz Vaz ${ }^{1}$ Paulo Santana Pacheco ${ }^{2}$ \\ Enio Júnior Seidel ${ }^{3}$ Angela Pellegrin Ansuj ${ }^{3}$
}

${ }^{1}$ Instituto de Educação, Agricultura e Ambiente (IEAA), Universidade Federal do Amazonas (UFAM), Campus Vale do Rio Madeira, 69800-000, Humaitá, AM, Brasil. E-mail: brazvaz@gmail.com. "Corresponding author.

${ }^{2}$ Programa de Pós-graduação em Zootecnia, Universidade Federal de Santa Maria (UFSM), Santa Maria, RS, Brasil.

${ }^{3}$ Departamento de Estatística, Universidade Federal de Santa Maria (UFSM), Santa Maria, RS, Brasil.

\begin{abstract}
This research was conducted to propose a classification of the coefficient of variation (CV\%) in many categories of variables of production and carcass of beef cattle experiments. The data was collected from theses and dissertations. We used the methods of classification considering mean and standard deviation, and considering median and pseudo-sigma. The two methods showed similar results so both can be used to classify CV\%. We propose only three categories to rank CV\%: low, medium and high.

Key words: animal science, animal experimentation, variability.
\end{abstract}

Classificação do coeficiente de variação para variáveis de experimentos com gado de corte

RESUMO: Neste trabalho propõe-se a classificação do coeficiente de variação (CV\%) para diversas categorias de variáveis de produção e carcaça de experimentos com gado de corte. Os dados foram coletados de teses e dissertações. Foram empregados métodos de classificação considerando média e desvio padrão, e considerando mediana e pseudo-sigma. Os dois métodos mostraram resultados similares e ambos podem ser utilizados para classificar o CV\%. Propõe-se, também, a classificação do CV\% em apenas três categorias: baixo, médio e alto. Palavras-chave: zootecnia, experimentação animal, variabilidade.

The coefficient of variation $(\mathrm{CV} \%)$ has been used by researchers to measure the variability of their experiments. To classify $\mathrm{CV} \%$ has been the subject of interest in several areas of the Brazilian agricultural survey. The first proposal was founded by GOMES (1985) which has been of great help and provides the basis for the comparison of different studies. According to GOMES (1985), CV\% is classified as low $(\mathrm{CV} \%<10 \%)$, medium $(\mathrm{CV} \%$ between $10 \%$ and $20 \%$ ), high (CV\% between $20 \%$ and 30\%), very high $(\mathrm{CV} \%>30 \%)$.

However, the classification of GOMES (1985) cannot be considered as valid for all studies. CLEMENT \& MUNIZ (2002) studying the CV\% in grasses, concluded that for different types of variables, the standard classification brought irregular interpretations. Thus, it is necessary to classify the $\mathrm{CV} \%$ particularly for each variable or area of interest.
GARCIA (1989) proposed a classification of $\mathrm{CV} \%$ in forest experiments by using mean and standard deviation. This methodology was also used later by several authors in their research (SCAPIM et al., 1995; AMARAL et al., 1997; JUDICE et al., 1999; CARVALHO et al., 2003). COSTA et al. (2002), considering aspects of the normal distribution of the $\mathrm{CV} \%$ proposed the use of median and pseudo-sigma to classify $\mathrm{CV} \%$. Other authors have also adopted the methodology based on COSTA et al. (2002) for the classification of the coefficient of variation (FARIA FILHO et al., 2010; COUTO et al., 2013.).

The median and pseudo-sigma measures are robust for cases of non-normality. In cases where there are normality, according to COSTA et al. (2002), using mean and standard deviation or median and pseudo-sigma generated similar results. Considering the animal production area, some attempts of the 
coefficient of variation classification were made by JUDICE et al. (1999), for pigs, JUDICE et al. (2002), in rearing beef cattle, MOHALLEM et al. (2008), in broilers, and FARIA FILHO et al. (2010), in laying. There is no studies about production and carcass beef cattle. In this scenario, this study proposed classification for the coefficient of variation for beef cattle production and carcass variables.

Data was collected from theses and dissertations of the Post-Graduate Program in Animal Science of the Universidade Federal de Santa Maria (PPGZ / UFSM). Material was selected only when contemplating beef cattle area and contained information about general mean, standard deviation or coefficient of variation.

In total, there was reported 54 scientific papers (7 from theses and 47 from dissertations) from 1991 to 2014 of which were obtained: category of the variable analyzed; coefficient of variation; general mean; standard deviation. Categories analyzed were: weight gain (41 data that indicate the average daily gain of animals in experiments); intake (251 data that indicated the animal food intake and its components); conversion (43 feed conversion data); behavior (69 data related to animal behavior); empty body components (EBC) in $\mathrm{kg}$ (220 data related to empty body components measured in kilograms); empty body components (EBC) in percentage (233 data related to empty body components measured in percentage); ratio (45 data that analyze the ratio between body components); yield (43 data of cold or hot cattle body yield); break (51 data related to freezing and cooking of cattle body yield); fat (82 data of measurements of fat in carcass components); metric (174 data of height, length or area of cattle body components). At the end, we had a total of 1252 observations.

We calculated minimum, maximum, mean, standard deviation, median and first and third quartiles of the sampling coefficient of variation in the different categories. We performed the Shapiro-Wilk test $(5 \%$ significance level) to verify the normality of the sampling distribution of $\mathrm{CV} \%$. Population coefficient of variation can be expressed by:

$\mathrm{CV} \%=\stackrel{\sigma}{\mu} \cdot 100$ where $\sigma$ is the population standard deviation and $\mu$ is the population general mean.

The first proposal of classification is based in GARCIA (1989) and follows: $\mathrm{CV} \% \leq_{\leq} \overline{\mathrm{x}}_{c v-} \mathrm{s}_{c v}$ rated

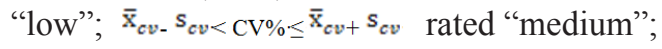
$\mathrm{CV} \%>\overline{\mathrm{x}}_{c v+} \mathrm{s}_{c v}$ "rated high", where $\overline{\mathrm{x}}_{c v}$ is the sampling mean of the coefficient of variation and $\mathrm{S}_{\mathrm{cv}}$ is the sampling standard deviation of the coefficient of variation. This method is more appropriate to variables with normal distribution.
The second proposal was based in COSTA et al. (2002) and follows: CV\% $\leq \mathrm{Md}_{\mathrm{cv}}$ - $\mathrm{PS}_{\mathrm{CV}}$ rated "low"; $\mathrm{Md}_{\mathrm{cv}}-\mathrm{PS}_{\mathrm{cv}}<\mathrm{CV} \% \leq \mathrm{Md}_{\mathrm{cv}}{ }^{\mathrm{cv}}$ $\mathrm{PS}_{\mathrm{cv}}$ rated "medium"; $\mathrm{CV} \%>\mathrm{Md}_{\mathrm{cv}}+\mathrm{PS}_{\mathrm{cv}}$ rated "high", where $\mathrm{Md}_{\mathrm{cv}}$ is the sampling median of the coefficient of variation and $\mathrm{PS}_{\mathrm{cv}}$ is the pseudo-sigma of the coefficient of variation. The pseudo-sigma, by COSTA et al. (2002), follows: $P S=\left(Q_{3}-Q_{1}\right) / 1,35$, where $\mathrm{Q}_{3}$ is the third quartile of sampling $C V \%$ and $\mathrm{Q}_{1}$ is the first quartile of sampling $\mathrm{CV} \%$. This method is more robust to non-normality cases.

Ours proposals uses only three category of classification for the coefficient of variation (low, medium and high) that differs from previous proposals. This change comes out by the fact that CV\% rated very high already means a high variability. Table 1 shows the descriptive analysis and results from the Shapiro-Wilk normality test. The minimum observed value of $\mathrm{CV} \%$ was $0.02 \%$ in metric category and the maximum observed value was $35.91 \%$ in empty body components in $\mathrm{kg}$ (Table 1). In general, to all categories was observed similar values between mean and median. Shapiro-Wilk normality test showed that only weight gain, ratio, yield and break follows a normal distribution (Table 1).

In table 2 we have the classifications for CV\% based on GARCIA (1989) and COSTA et al. (2002). Results are similar to both classification, even if, as can be seen in Table 1, most data showed no normality. We observed, in general, that the range of coefficient of variation was low, exception for yield. The highest limit to consider $\mathrm{CV} \%$ low was $12 \%$ and the highest limit to consider CV\% high was 23\% (Table 2).

For example, weight gain was classified low $\mathrm{CV} \%$ if less than $12 \%$ (or $11 \%$ ), medium CV\% if between $12 \%$ and $20 \%$, and high CV\% if bigger than $20 \%$ (Table 2). JUDICE et al. (2002) in beef cattle, using mean and standard deviation, classified $\mathrm{CV} \%$ to weight gain as low if less than $10.25 \%$, medium $\mathrm{CV} \%$ if between $10.25 \%$ and $31.57 \%$, high $\mathrm{CV} \%$ if between $31.57 \%$ and $61.66 \%$ and very high if bigger than $61.66 \%$. We can see similar values to classify low $\mathrm{CV} \%$ in both proposals; however, the upper limit to rate $\mathrm{CV} \%$ medium to high have differences. Besides that, JUDICE et al. (2002) considered using the very high rate of $\mathrm{CV} \%$, that differs from this study.

In the intake category of variables $\mathrm{CV} \%$ the limit between low and medium rate was $4 \%$, while for JUDICE et al. (2002) was 2.89\%. The limit to classify $\mathrm{CV} \%$ between medium and high was $10 \%$ while for JUDICE et al. (2002) was 7.63\%. These values can be considered close, showing that for this category were reported similar results. 
Table 1 - Minimum, mean, median, maximum, first quartile $\left(\mathrm{Q}_{1}\right)$, third quartile $\left(\mathrm{Q}_{3}\right)$, sampling size (n) and p-value of Shapiro-Wilk test (SW) for coefficient of variation $(\%)$.

\begin{tabular}{|c|c|c|c|c|c|c|c|c|}
\hline Category & Minimum & Mean & Median & Maximum & $\mathrm{Q}_{1}$ & $\mathrm{Q}_{3}$ & $\mathrm{n}$ & SW \\
\hline Weight gain & 7.10 & 16.10 & 15.49 & 23.78 & 13.39 & 20.00 & 38 & 0.54 \\
\hline Intake & 1.44 & 7.53 & 7.13 & 14.76 & 5.54 & 9.33 & 234 & $<0.01$ \\
\hline Conversion & 3.38 & 12.13 & 12.37 & 20.82 & 8.06 & 16.49 & 41 & 0.01 \\
\hline Behavior & 1.21 & 11.48 & 10.19 & 26.53 & 7.70 & 15.44 & 60 & $<0.01$ \\
\hline $\mathrm{EBC}$ in $\mathrm{kg}$ & 1.42 & 14.56 & 12.33 & 35.91 & 7.10 & 19.79 & 202 & $<0.01$ \\
\hline $\mathrm{EBC}$ in $\%$ & 0.61 & 7.99 & 6.60 & 23.15 & 3.08 & 11.15 & 212 & $<0.01$ \\
\hline Ratio & 1.04 & 11.00 & 11.46 & 21.96 & 6.40 & 14.54 & 42 & 0.26 \\
\hline Yield & 0.46 & 2.55 & 2.56 & 5.33 & 1.58 & 3.14 & 41 & 0.15 \\
\hline Break & 0.11 & 14.19 & 14.38 & 28.73 & 10.24 & 18.96 & 45 & 0.15 \\
\hline Fat & 2.07 & 12.99 & 12.56 & 28.66 & 7.31 & 18.05 & 78 & 0.04 \\
\hline Metric & 0.02 & 5.77 & 4.95 & 14.32 & 3.28 & 7.84 & 141 & $<0.01$ \\
\hline
\end{tabular}

In JUDICE et al. (1999), classifying CV\% for pigs, we have the categories weight gain, feed conversion, feed intake and carcass yield. There were similar results to this study, especially for yield category, with the limit to classify between low and medium of $1.17 \%$ while this study was $1.40 \%$. To the limit between medium and high, we have $3.12 \%$ for JUDICE et al. (1999) while for this study was 3.70\%. Considering the categories weight gain and intake, as noted in table 2, there were similar

Table 2 - Proposed classification of the coefficient of variation based on GARCIA (1989) and COSTA et al. (2002).

\begin{tabular}{|c|c|c|c|}
\hline Variable & Low & Medium & High \\
\hline Weight gain & $\mathrm{CV} \% \leq 12 \%$ & $12 \%<\mathrm{CV} \% \leq 20 \%$ & $\mathrm{CV} \%>20 \%$ \\
\hline Intake & $\mathrm{CV} \% \leq 4 \%$ & $4 \%<\mathrm{CV} \% \leq 10 \%$ & $\mathrm{CV} \%>10 \%$ \\
\hline Conversion & $\mathrm{CV} \% \leq 7 \%$ & $7 \%<\mathrm{CV} \% \leq 17 \%$ & $\mathrm{CV} \%>17 \%$ \\
\hline Behavior & $\mathrm{CV} \% \leq 5 \%$ & $5 \%<\mathrm{CV} \% \leq 18 \%$ & $\mathrm{CV} \%>18 \%$ \\
\hline $\mathrm{EBC}$ in $\mathrm{kg}$ & $C V \% \leq 6 \%$ & $6 \%<\mathrm{CV} \% \leq 23 \%$ & $\mathrm{CV} \%>23 \%$ \\
\hline $\mathrm{EBC}$ in $\%$ & $\mathrm{CV} \% \leq 2 \%$ & $2 \%<\mathrm{CV} \% \leq 14 \%$ & $\mathrm{CV} \%>14 \%$ \\
\hline Ratio & $\mathrm{CV} \% \leq 5 \%$ & $5 \%<\mathrm{CV} \% \leq 17 \%$ & $\mathrm{CV} \%>17 \%$ \\
\hline Yield & $\mathrm{CV} \% \leq 1.4 \%$ & $1.4 \%<\mathrm{CV} \% \leq 3.7 \%$ & $\mathrm{CV} \%>3.7 \%$ \\
\hline Break & $\mathrm{CV} \% \leq 6 \%$ & $6 \%<\mathrm{CV} \% \leq 22 \%$ & $\mathrm{CV} \%>22 \%$ \\
\hline Fat & $\mathrm{CV} \% \leq 6 \%$ & $6 \%<\mathrm{CV} \% \leq 20 \%$ & $\mathrm{CV} \%>20 \%$ \\
\hline Metric & $\mathrm{CV} \% \leq 2 \%$ & $2 \%<\mathrm{CV} \% \leq 9 \%$ & $\mathrm{CV} \%>9 \%$ \\
\hline --------- & Low & $\begin{array}{c}\text { on COSTA et al. (2002) } \\
\text { Medium }\end{array}$ & High \\
\hline Weight gain & $\mathrm{CV} \% \leq 11 \%$ & $11 \%<\mathrm{CV} \% \leq 20 \%$ & $\mathrm{CV} \%>20 \%$ \\
\hline Intake & $\mathrm{CV} \% \leq 4 \%$ & $4 \%<\mathrm{CV} \% \leq 10 \%$ & $\mathrm{CV} \%>10 \%$ \\
\hline Conversion & $\mathrm{CV} \% \leq 6 \%$ & $6 \%<\mathrm{CV} \% \leq 19 \%$ & $\mathrm{CV} \%>19 \%$ \\
\hline Behavior & $\mathrm{CV} \% \leq 4 \%$ & $4 \%<\mathrm{CV} \% \leq 16 \%$ & $\mathrm{CV} \%>16 \%$ \\
\hline $\mathrm{EBC}$ in $\mathrm{kg}$ & $\mathrm{CV} \% \leq 3 \%$ & $3 \%<\mathrm{CV} \% \leq 22 \%$ & $\mathrm{CV} \%>22 \%$ \\
\hline $\mathrm{EBC}$ in $\%$ & $\mathrm{CV} \% \leq 1 \%$ & $1 \%<\mathrm{CV} \% \leq 13 \%$ & $\mathrm{CV} \%>13 \%$ \\
\hline Ratio & $\mathrm{CV} \% \leq 5 \%$ & $5 \%<\mathrm{CV} \% \leq 17 \%$ & $\mathrm{CV} \%>17 \%$ \\
\hline Yield & $\mathrm{CV} \% \leq 1.4 \%$ & $1.4 \%<\mathrm{CV} \% \leq 3.7 \%$ & $\mathrm{CV} \%>3.7 \%$ \\
\hline Break & $\mathrm{CV} \% \leq 8 \%$ & $8 \%<\mathrm{CV} \% \leq 21 \%$ & $\mathrm{CV} \%>21 \%$ \\
\hline Fat & $\mathrm{CV} \% \leq 5 \%$ & $5 \%<\mathrm{CV} \% \leq 21 \%$ & $\mathrm{CV} \%>21 \%$ \\
\hline Metric & $\mathrm{CV} \% \leq 2 \%$ & $2 \%<\mathrm{CV} \% \leq 8 \%$ & $\mathrm{CV} \%>8 \%$ \\
\hline
\end{tabular}


results to those obtained by JUDICE et al. (2002), and categories weight gain, intake, conversion and yield, the results were similar to those obtained by JUDICE et al. (1999).

FARIA FILHO et al. (2010), with layers and MOHALLEM et al. (2008), with broiler chickens, smaller amplitudes were observed for the coefficient of variation, which differs from the results obtained in this study. This is due to the fact that experiments with chickens have less variability.

In general, both range of the $\mathrm{CV} \%$ as the boundaries between the categories of classification, in this study, are lower than those proposed by GOMES (1985), noting that this study did not consider categorizing $\mathrm{CV} \%$ as very high. We recommend the use of this new intervals of classifications of $\mathrm{CV} \%$ for experiments with beef cattle. In general, the intervals for cattle experiments have smaller range to those proposed in the classical literature.

The two methods used to classify the coefficient of variation generated similar results to variables of bovine production and carcass category. Any of them can be applied to classifications of $\mathrm{CV} \%$. The classification of the $\mathrm{CV} \%$ in three categories (low, medium and high) is sufficient to measure the accuracy of experiments.

\section{ACKNOWLEDGEMENTS}

We thank to the Programa de Pós-graduação em Zootecnia (PPGZ) of Universidade Federal de Santa Maria for all the suport in this research.

\section{REFERENCES}

AMARAL, A.M. do et al. Avaliação do coeficiente de variação como medida de precisão na experimentação com citros. Pesquisa Agropecuária Brasileira, Brasília, v.32, n.12, p.1221-1225, 1997. Available from: $<$ https://seer.sct.embrapa.br/index.php/pab/article/ viewFile/4774/7248>. Accessed: Jan. 19, 2015.

CARVALHO, C.G.P. et al. Proposta de classificação dos coeficientes de variação em relação a produtividade e altura da planta de soja. Pesquisa Agropecuária Brasileira, Brasília, v.38, n.2, p.187-193, 2003. Available from: $\quad<$ https://seer.sct.embrapa.br/index.php/pab/article/view/6559>. Accessed: Jan. 21, 2015. doi: 10.1590/S0100-204X2003000200004.

COSTA, N.H. de A.D. et al. Novo método de classificação de coeficiente de variação para a cultura do arroz de terras altas. Pesquisa Agropecuária Brasileira, Brasília, v.37, n.3, p.243-249, 2002. Available from: <http://www.scielo.br/pdf/pab/v37n3/8996.pdf >. Accessed: Jan. 19, 2015. doi: 10.1590/S0100-204X2002000300003.

COUTO, M.F. et al. Classificação dos coeficientes de variação para a cultura da cana de açúcar. Ciência Rural, Santa Maria, v.46, n.6, p.957-961,2013. Available from: <http://revistas.bvs-vet.org.br/crural/ article/view/21823>. Accessed: Jan. 20, 2015. doi: 10.1590/S010384782013000600003 .

FARIA FILHO, D.E. et al. Classification of coefficients of variation in experiments with commercial layers. Revista Brasileira de Ciência Avícola, Campinas, v.12, n.4, p.255-257, 2010. Available from: $<$ http://www.scielo.br/scielo.php?script=sci_arttext\&pid=S1516635X2010000400006>. Accessed: Jan. 20, 2015. doi: 10.1590/ S1516-635X2010000400006

GARCIA, C.H. Tabelas para classificação do coeficiente de variação. Piracicaba: Ipef, 1989. 12p. (Circular técnica, 171). Available from: $<$ http://www.ipef.br/publicacoes/ctecnica/nr171. pdf>. Accessed: Nov 11, 2014.

GOMES, F.P. Curso de estatística experimental. São Paulo: Nobel, 1985. 467p.

JUDICE, M.G. et al. Avaliação do coeficiente de variação na experimentação com suínos. Ciência e Agrotecnologia, Lavras, v.23, n.1.p.170-173, 1999. Available from: <http://www.editora.ufla.br/index. $\mathrm{php} /$ component/phocadownload/category/35-volume-23-numero-1nov a?download=517:vol23numerolnova $>$. Accessed: Jan. 20, 2015.

JUDICE, M.G. et al. Avaliação da precisão experimental em ensaios com bovinos de corte. Ciência e Agrotecnologia, Lavras, v.26, n.5, p.1035-1040, 2002. Available from: <http://www.editora.ufla. br/index.php/component/phocadownload/category/49-volume-26numero-5?download=876:vol26numero5>. Accessed: Jan. 20, 2015.

MOHALLEM, D.F. et al. Avaliação do coeficiente de variação como medida da precisão em experimentos com frangos de corte. Arquivo Brasileiro de Medicina Veterinária Zootecnia, Belo Horizonte, v.60, p.449-453, 2008. Available from: <http://www.scielo.br/ scielo.php?script $=$ sci_arttext\&pid=S0102-09352008000200026>. Accessed: Jan. 25, 2015. doi: 10.1590/S0102-09352008000200026.

SCAPIM, C.A. et al. Uma proposta de classificação dos coeficientes de variação para a cultura do milho. Pesquisa Agropecuária Brasileira, Brasília, v.30, n.5, p.683-686, 1995. Available from: <https://seer.sct. embrapa.br/index.php/pab/article/view/4353>. Accessed: Jan. 15, 2015. 